\title{
Economic Crises And Entrepreneurship: A Comparison Of Developed And Less Developed Countries
}

https://doi.org/10.21272/sec.5(4).5-23.2021

Halil Dincer Kaya, ORCID ID: https://orcid.org/0000-0002-7535-9857

Professor of Finance, Department of Accounting and Finance, College of Business and Technology, Northeastern State University, Broken Arrow, OK, USA

\begin{abstract}
This paper examines the change in entrepreneurial activity in developed and less developed countries during the period surrounding the 2008-2009 Global Crisis. The paper also examines how several entrepreneurship-related factors including costs, taxes, number of procedures, legal rights and credit coverage had changed for the two groups of countries after the Global Crisis. For the developed nations, we find that most factors had not significantly changed from the pre-crisis period to the post-crisis period. Out of the eighteen factors that are examined, only three had significantly changed. The cost to export had worsened (i.e. increased), while the number of tax payments and the time required to start a business had improved (i.e. declined). When we look at new business formation, we find that for the developed nations, there was no significant change in new business density and new business registrations. For the less developed nations, we find that most factors had significantly changed from the pre-crisis period to the post-crisis period. Out of the eighteen factors that are examined, fifteen had significantly changed (i.e. two of them worsened and thirteen of them improved). The "cost to export" and the "cost to import" both worsened (i.e. increased). On the other hand, the cost of business start-up procedures, the number of tax payments, the total tax rate, the legal rights, the number of procedures to register property, to start a business, the time required to build a warehouse, to register property, to start a business, to prepare and pay taxes, the credit depth, the private credit bureau coverage, and the public credit registry coverage all improved. For the less developed nations, similar to the developed nations, we find that there was no significant change in new business density and new business registrations. We conclude that, in terms of the entrepreneurial environment, the Global Crisis had a more negative impact on less developed nations when compared to developed nations. While entrepreneurial activity had not significantly changed in both groups, the less developed countries achieved this by improving several different aspects of the entrepreneurial environment. In order to protect their entrepreneurs, they had to be more proactive when compared to the developed nations.
\end{abstract}

Keywords: entrepreneur, entrepreneurship, small business, economic crisis, recession push, prosperity pull.

JEL Classification: E32, G01, H12, L26.

Cite as: Kaya, H.D. (2021). Economic Crises And Entrepreneurship: A Comparison Of Developed And Less Developed Countries. SocioEconomic Challenges, 5(4), 5-23. https://doi.org/10.21272/sec.5(4).5-23.2021.

Received: 16.07 .2021

Accepted: 13.10 .2021

Published: 30.12 .2021

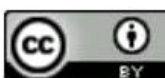

Copyright: (C) 2021 by the author. Licensee Sumy State University, Ukraine. This article is an open access article distributed under the terms and conditions of the Creative Commons Attribution (CC BY) license (https://creativecommons.org/licenses/by/4.0/).

\section{Introduction}

In this study, we examine how entrepreneurial activity had changed in developed and less developed countries in the wake of the 2008-2009 Global Financial Crisis. Besides examining the trend in entrepreneurial activity in developed and less developed countries, we also examine how the trend in several entrepreneurship-related 
factors differ for these two groups during this period. These factors include measures on taxes, legal rights, costs, number of procedures, and credit coverage of entrepreneurs.

In this paper, we argue that entrepreneurial environment in developed countries are less prone to changes in the macroeconomic environment due to their more established institutional and regulatory framework. Also, in these countries, the overall initial strength of the economy at the start of the crisis should serve as a shield for their entrepreneurial environment. Therefore, we expect the entrepreneurial environment to be more intact after the crisis for these countries when compared to less developed countries. In other words, in developed countries, we expect to see both the entrepreneurial activity and the factors that affect the activity to be more stable throughout this period when compared to less developed nations.

Previous papers on the topic include country or region-specific papers. Here, we do a global analysis. We examine 80 countries ( 25 of which are classified as "developed" based on their per capita incomes). Our main contribution is to show the efforts of developed and less developed countries in protecting their entrepreneurial environment in the wake of the global crisis. Our results show that, as expected, in order to protect their entrepreneurial environment, the less developed nations in our sample had to be more proactive when compared to the developed nations. Out of the 18 factors that are examined, 13 had improved in the less developed countries, while only one had improved in the developed countries. In other words, while entrepreneurial activity was stable after the crisis for both groups, the less developed nations achieved this by improving several areas including costs, taxes, procedures, legal rights, and credit coverage.

In the next section, we go over the previous literature. In Section 3, we explain our data and methodology. In Section 4, we show the results of our empirical tests. The final section concludes.

\section{Literature Review}

The previous studies linking the business cycle and entrepreneurship fall into two camps. The first camp believes that the business cycle is positively related to entrepreneurial activity (i.e. pro-cyclical relationship). This hypothesis is named the "Prosperity Pull" hypothesis. The second camp believes that the business cycle is negatively related to entrepreneurial activity (i.e. counter-cyclical relationship). This second hypothesis is named the "Recession Push" hypothesis.

Kim and Cho (2009) and Parker (2018) support the "Prosperity Pull" hypothesis. They argue that risks (i.e. the risk of failure for the business and the risk of not being able to find a salaried/hourly job it the business fails) are lower for potential entrepreneurs during economic expansions, therefore they tend to start their own business during these good times. Blanchflower and Oswald (1998), Cagetti and De Nardi (2006), and Holtz-Eakin, et al. (1994) also support the "Prosperity Pull" hypothesis. According to these studies, recessions cause borrowing opportunities to go down, therefore it is much harder to start a business during these times. Rampini (2004) supports this view and argues that even if potential entrepreneurs have access to financial intermediaries, recessions cause entrepreneurial activity to go down. Shane (2011) and Yu, Orazem, and Jolly (2014) examine the U.S. data and these studies both support the "Prosperity Pull" hypothesis for the U.S. Blanchflower (2000) examines several OECD countries and shows that there is a negative relationship between the unemployment rate and the self-employment rate in most of these countries.

Both Parker (2018) and Congregado et al. (2012) do a detailed literature review on the topic. Parker (2018) supports the "Prosperity Pull" hypothesis for the U.S. The author explains this pro-cyclical relationship by two factors: 1) the reduced costs (i.e. wages and salaries) for potential entrepreneurs during recessions, and 2) the failure of some small businesses which would be replaced by new firms during recessions.

Besides these several studies fully supporting the "Prosperity Pull" hypothesis, two other studies only partially support the hypothesis. Brünjes and Diez (2013) separated entrepreneurial activities as opportunity-driven and necessity-driven activities and show that the hypothesis works for opportunity-driven entrepreneurship but not for necessity-driven entrepreneurship. Figueroa-Armijos, Dabson and Johnson (2012) also differentiate between the two types of entrepreneurship and showed that the 2008-2009 Great Recession reduced opportunity entrepreneurship and increased necessity entrepreneurship. 
While all of these studies support the "Prosperity Pull" hypothesis, several others including Constant and Zimmermann (2004), Evans and Leighton (1989), and Moore and Mueller (2002) support the "Recession Push" hypothesis. According to these studies, during recessions, the labor market becomes weaker, therefore individuals are forced to start their own business due to the lack of hourly/salaried positions. Fairlie (2013) examines how the 2008-2009 Great Recession changed the entrepreneurial environment in the U.S. Fairlie (2013) shows that entrepreneurial activity in the U.S. increased during this period. Koellinger and Thurik (2012) also support the "Recession Push" hypothesis. They examine 22 OECD countries and show that, in these countries, higher unemployment rates have caused more entrepreneurial activity.

In this current study, we argue that the differences in previous studies' findings stem from the characteristics of the sample country/countries. We argue that developed nations have a better institutional framework and a stronger economy when compared to less developed nations and that this helps them in protecting their entrepreneurial environment better when facing a macroeconomic shock. In other words, we contend that entrepreneurial activity in less developed nations is more negatively affected during a recession due to their weaker institutional framework and less stable economy. While we expect to see a larger negative impact on entrepreneurial activity in less developed nations, we expect governments in these countries to be more proactive in trying to protect their entrepreneurial environment.

In this current study, we are hoping to contribute to the literature by examining the entrepreneurial activity in 25 developed and 55 less developed countries during the 2008-2009 Great Recession. Was entrepreneurial activity in less developed nations affected more negatively due to the Great Recession? We also examine how several entrepreneurship-related factors including taxes, costs, legal rights, credit coverage, and procedures had changed during the Great Recession. Were governments in less developed nations more proactive in protecting their entrepreneurial environment (i.e. by altering the costs, taxes, and other factors that would affect potential entrepreneurs)?

\section{Data and Methodology}

The data on entrepreneurship are accessed through two different World Bank websites. These two websites are http://econ.worldbank.org/research/entrepreneurship" and "http://www.doingbusiness.org". Our sample period covers the 2008-2009 crisis period as well as the three-year period leading up to the crisis period and the threeyear period following the crisis period (i.e. 2005-2012). Out of the 80 countries that have complete data on these websites, 25 were classified as "Developed" and 55 were classified as "Less Developed" (i.e. according to their 2005 income per capita values).

We examine how new business formation had changed after the crisis. We also examine how several factors affecting the entrepreneurial environment had changed after the crisis. In order to make the comparisons between the per-crisis period and the post-crisis period, we run non-parametric tests (i.e. Mann-Whitney Wilcoxon tests).

Our variable definitions are as follows:

Costofbusstartupproc: Cost of business start-up procedures as a percentage of Gross National Income per capita

Costtoexport: Cost to export per container in U.S. dollars

Costtoimport: Cost to import per container in U.S. dollars

Creditdepth: The "Credit depth of information index" which ranges from 0 to 6 .

Newbusden: New business density or number of new registrations per 1,000 people ages 15-64

Newbusreg: Number of new businesses registered

Prcreditbureau: Percentage of adults with private credit bureau coverage

Proctobuildaware: Number of procedures to build a warehouse 
SocioEconomic Challenges, Volume 5, Issue 4, 2021

ISSN (print) - 2520-6621, ISSN (online) - 2520-6214

Proctoenforceacont: Number of procedures to enforce a contract

Proctoregisterprop: Number of procedures to register property

Pucreditregistrycov: Percentage of adults with public credit registry coverage

Startupproctoregabus: Number of Start-up procedures to register a business

Strengthoflegalrightsind: The "Strength of legal rights index" which ranges from 0 to 10

Taxpayments: Number of tax payments

Timereqtobuildaware: Number of days required to build a warehouse

Timereqtoenforceacont: Number of days required to enforce a contract

Timereqtoregprop: Number of days required to register property

Timereqtostartabus: Number of days required to start a business

Timetoprepandpaytaxes: Number of hours required to prepare and pay taxes

Totaltaxrate: The total tax rate as a percentage of commercial profits

Table 1 shows the summary statistics for the developed countries and less developed countries over our sample period which is from year 2005 through year 2012.

Table 1. Summary Statistics

\begin{tabular}{|c|c|c|c|c|c|c|}
\hline & \multicolumn{3}{|c|}{ Developed } & \multicolumn{3}{|c|}{ Less Developed } \\
\hline & Mean & Median & Std & Mean & Median & Std \\
\hline Costofbusstartupproc & 3.9 & 1.8 & 5.1 & 38.2 & 12.6 & 100.7 \\
\hline Costtoexport & 958.5 & 930.0 & 320.9 & $1,412.6$ & $1,210.0$ & 894.2 \\
\hline Costtoimport & 984.3 & $1,005.0$ & 350.5 & $1,641.1$ & $1,425.0$ & $1,046.5$ \\
\hline Creditdepth & 4.8 & 5.0 & 0.9 & 3.3 & 4.0 & 2.3 \\
\hline Newbusden & 5.8 & 4.0 & 5.8 & 2.5 & 1.2 & 3.3 \\
\hline Newbusreg & $66,573.9$ & $27,519.0$ & $86,599.9$ & $27,802.4$ & $8,422.5$ & $68,744.3$ \\
\hline Prcreditbureau & 59.2 & 71.7 & 40.2 & 24.1 & 3.9 & 32.0 \\
\hline Proctobuildaware & 11.7 & 11.0 & 3.3 & 17.7 & 16.0 & 8.1 \\
\hline Proctoenforceacont & 31.2 & 30.0 & 6.6 & 37.4 & 37.0 & 6.0 \\
\hline Proctoregisterprop & 4.4 & 5.0 & 1.9 & 6.2 & 6.0 & 2.6 \\
\hline Pucreditregistrycov & 7.9 & 0.0 & 17.9 & 6.9 & 0.0 & 13.1 \\
\hline Startupproctoregabus & 5.1 & 5.0 & 2.5 & 8.3 & 8.0 & 3.3 \\
\hline Strengthoflegalrightsind & 7.5 & 7.0 & 2.0 & 5.6 & 6.0 & 2.3 \\
\hline Taxpayments & 9.9 & 9.0 & 4.5 & 34.3 & 32.0 & 25.1 \\
\hline Timereqtobuildaware & 145.1 & 142.0 & 63.6 & 223.8 & 199.0 & 161.2 \\
\hline Timereqtoenforceacont & 441.6 & 397.0 & 215.9 & 650.7 & 565.0 & 340.3 \\
\hline Timereqtoregprop & 28.3 & 18.3 & 31.5 & 81.4 & 50.3 & 99.4 \\
\hline Timereqtostartabus & 12.4 & 11.0 & 10.0 & 42.8 & 25.0 & 90.0 \\
\hline Timetoprepandpaytaxes & 138.4 & 127.0 & 71.6 & 393.9 & 302.0 & 378.4 \\
\hline Totaltaxrate & 41.6 & 40.7 & 14.9 & 45.9 & 38.3 & 30.7 \\
\hline
\end{tabular}

Note: Author's own work.

\section{Empirical Results}

Table 2 shows the trend in each variable for the developed countries over the 2005-2012 period. Table 3 shows the trend in each variable for the less-developed countries over the 2005-2012 period. The figures below the two tables show how each variable had changed over that period for developed and less-developed countries. 
Table 2. Variables for Developed Countries over time (medians)

\begin{tabular}{|l|c|c|c|c|c|c|c|c|}
\hline & $\mathbf{2 0 0 5}$ & $\mathbf{2 0 0 6}$ & $\mathbf{2 0 0 7}$ & $\mathbf{2 0 0 8}$ & $\mathbf{2 0 0 9}$ & $\mathbf{2 0 1 0}$ & $\mathbf{2 0 1 1}$ & $\mathbf{2 0 1 2}$ \\
\hline Costofbusstartupproc & 3.05 & 2 & $\mathbf{2 0}$ & $\mathbf{1 . 5}$ & 1.35 & 1.45 & 1.4 & 1.35 \\
\hline Costtoexport & 884 & 884 & 904 & 1067.5 & 1057.5 & 1027.5 & 1027.5 & 1045 \\
\hline Costtoimport & 959 & 959 & 959 & 1070.5 & 1030.5 & 993.5 & 1010 & 1072.5 \\
\hline Creditdepth & 5 & 5 & 5 & 5 & 5 & 5 & 5 & 5 \\
\hline Newbusden & 3.8538 & 4.3499 & 4.5896 & 4.2644 & 3.7106 & 3.8215 & 3.6566 & 3.6185 \\
\hline Newbusreg & 20715 & 29372 & 26965 & 25549 & 24232 & 31096 & 36114 & 35398 \\
\hline Prcreditbureau & 62.2 & 66.15 & 68.1 & 72.4 & 74.7 & 76.25 & 84.75 & 85.55 \\
\hline Proctobuildaware & 11 & 11 & 11 & 11 & 11 & 11 & 11 & 11 \\
\hline Proctoenforceacont & 30 & 30 & 30 & 30 & 30 & 30 & 30 & 30 \\
\hline Proctoregisterprop & 5 & 5 & 5 & 5 & 5 & 5 & 5 & 5 \\
\hline Pucreditregistrycov & 0 & 0 & 0 & 0 & 0 & 0 & 0 & 0 \\
\hline Startupproctoregabus & 5 & 5 & 5 & 5 & 4.5 & 4.5 & 4.5 & 4.5 \\
\hline Strengthoflegalrightsind & 7.5 & 7.5 & 7.5 & 7 & 7.5 & 7.5 & 7.5 & 7.5 \\
\hline Taxpayments & 10.5 & 10.5 & 9.5 & 9 & 9 & 8.5 & 8.5 & 8 \\
\hline Timereqtobuildaware & 148 & 148 & 148 & 142.5 & 117.5 & 135 & 135 & 126 \\
\hline Timereqtoenforceacont & 400.5 & 400.5 & 400.5 & 400.5 & 396 & 398 & 396 & 396 \\
\hline Timereqtoregprop & 20.5 & 18.75 & 18.75 & 18.25 & 18.25 & 18.25 & 16.25 & 18.25 \\
\hline Timereqtostartabus & 13 & 13 & 12.5 & 10.5 & 9 & 7.5 & 7.5 & 6.75 \\
\hline Timetoprepandpaytaxes & 127 & 127 & 127 & 127 & 127 & 131.5 & 124.5 & 124.5 \\
\hline Totaltaxrate & 47.6 & 44.8 & 43.05 & 42.4 & 41.5 & 40.05 & 38.85 & 38.95 \\
\hline
\end{tabular}

Note: Author's own work.

Table 3. Variables for Less-Developed Countries over time (medians)

\begin{tabular}{|l|c|c|c|c|c|c|c|c|}
\hline & $\mathbf{2 0 0 5}$ & $\mathbf{2 0 0 6}$ & $\mathbf{2 0 0 7}$ & $\mathbf{2 0 0 8}$ & $\mathbf{2 0 0 9}$ & $\mathbf{2 0 1 0}$ & $\mathbf{2 0 1 1}$ & $\mathbf{2 0 1 2}$ \\
\hline Costofbusstartupproc & 23.15 & $\mathbf{2 0}$ & $\mathbf{1 5 . 8 5}$ & 12.05 & 10.4 & 10.75 & 10.1 & 9.7 \\
\hline Costtoexport & 1118.5 & 1084.5 & 1070 & 1229 & 1266.5 & 1278 & 1327.5 & 1331 \\
\hline Costtoimport & 1248.5 & 1205 & 1197.5 & 1335 & 1429.5 & 1447.5 & 1517.5 & 1542.5 \\
\hline Creditdepth & 3 & 3 & 4 & 4 & 4 & 4 & 4 & 5 \\
\hline Newbusden & 0.9426 & 1.1242 & 1.185 & 1.1741 & 1.1938 & 1.19 & 1.2247 & 1.3636 \\
\hline Newbusreg & 6963.5 & 7013 & 8208.5 & 8834.5 & 7893 & 9411.5 & 10066 & 10212 \\
\hline Prcreditbureau & 0 & 0 & 0.8 & 3.75 & 6.15 & 10.2 & 16.55 & 12.35 \\
\hline Proctobuildaware & 17 & 16.5 & 16 & 16 & 16 & 16 & 16 & 15 \\
\hline Proctoenforceacont & 37 & 37 & 37 & 37 & 36.5 & 36.5 & 36 & 36 \\
\hline Proctoregisterprop & 6 & 6 & 6 & 6 & 6 & 6 & 6 & 6 \\
\hline Pucreditregistrycov & 0 & 0 & 0 & 0 & 0 & 0 & 0.05 & 0 \\
\hline Startupproctoregabus & 9 & 9 & 9 & 8 & 7 & 7 & 6 & 6 \\
\hline Strengthoflegalrightsind & 5 & 5 & 5 & 6 & 6 & 6 & 6 & 6 \\
\hline Taxpayments & 34.5 & 34 & 33.5 & 31.5 & 30.5 & 30.5 & 29.5 & 26.5 \\
\hline Timereqtobuildaware & 212.25 & 212.25 & 211 & 201.5 & 189.5 & 187.5 & 187.5 & 166.5 \\
\hline Timereqtoenforceacont & 565 & 564.5 & 564.5 & 577.5 & 575 & 575 & 567.5 & 571 \\
\hline Timereqtoregprop & 65.5 & 62.5 & 57.75 & 51 & 46 & 42.5 & 37.5 & 36.75 \\
\hline Timereqtostartabus & 34.5 & 32 & 29.5 & 25 & 20 & 18.75 & 17.75 & 16.5 \\
\hline Timetoprepandpaytaxes & 320 & 320 & 314 & 292 & 280.5 & 278 & 278 & 274.5 \\
\hline Totaltaxrate & 40.6 & 38.95 & 38.5 & 38.35 & 37.05 & 37 & 36.45 & 36.1 \\
\hline
\end{tabular}

Note: Author's own work. 
Figure 1 shows that the cost of business start-up procedures went down especially in the earlier period for both groups. However, the decline in this cost was much more pronounced for the less-developed economies. For the lessdeveloped countries, it dropped from $23.15 \%$ of GNI per capita in 2005 to $9.7 \%$ of GNI per capita in 2012. For the developed countries, it dropped from 3.05\% of GNI per capita in 2005 to $1.35 \%$ of GNI per capita in 2012.

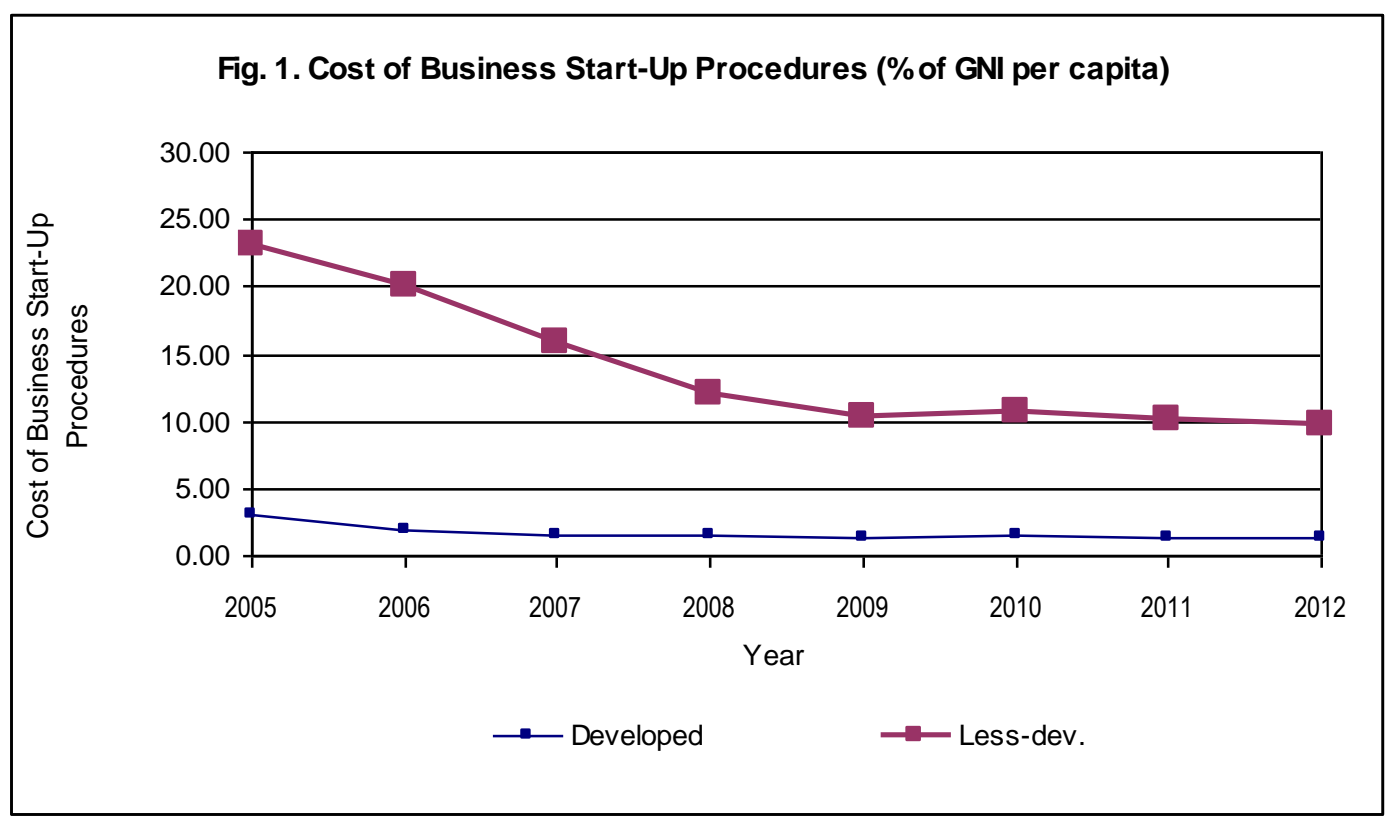

Source: Author's own work.

Figure 2 shows that the time required to start a business also went down for both groups. Again, the decline was more pronounced for the less-developed countries. For the less-developed countries, it dropped from 34.5 days in 2005 to 16.5 days in 2012. For the developed countries, it dropped from 13 days in 2005 to 6.75 days in 2012.

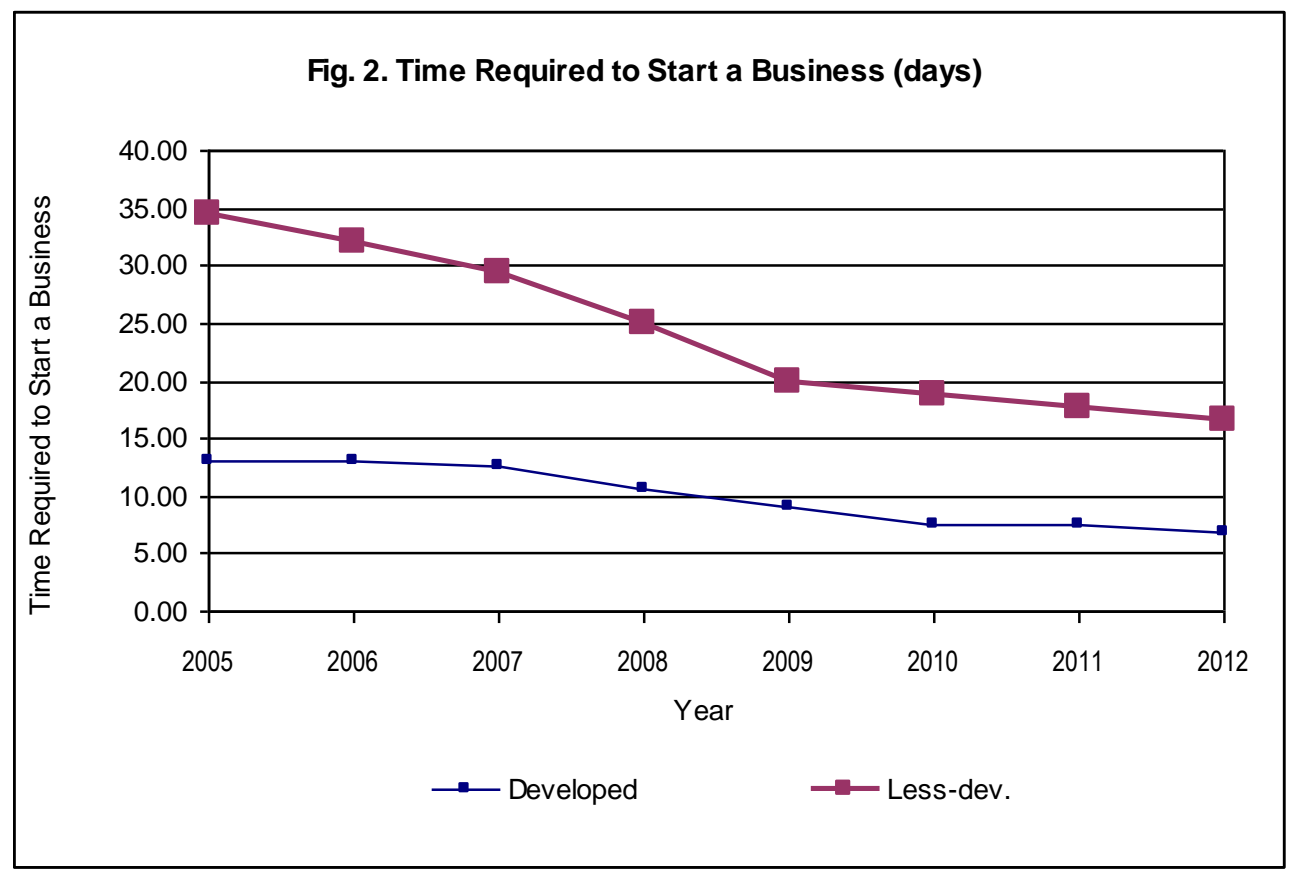

Source: Author's own work. 
Figure 3 shows that the number of start-up procedures went down for both groups. Again, the decline was much more pronounced for the less-developed economies. For the less-developed countries, it dropped from 9 in 2005 to 6 in 2012. For the developed countries, it dropped from 5 in 2005 to 4.5 in 2012.

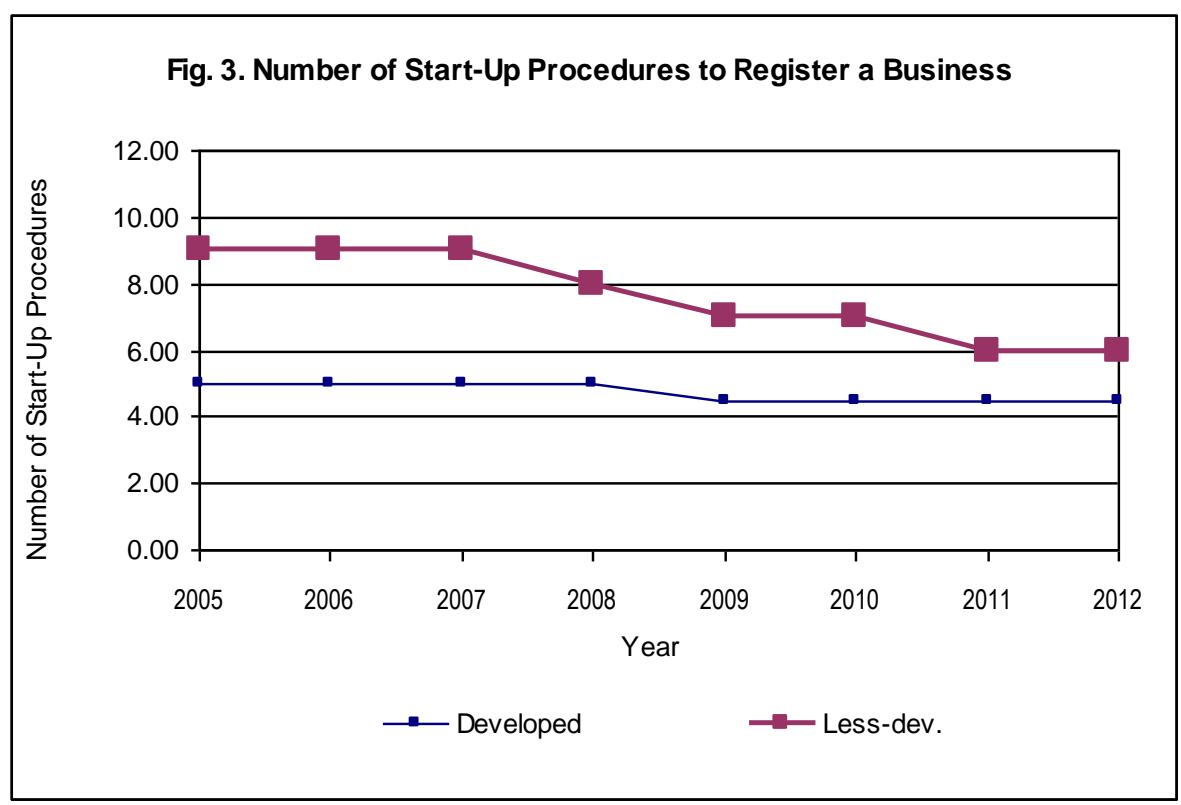

Source: Author's own work.

Figure 4 shows the trend in the "Credit depth of information index". For this measure, we are seeing an improvement over time for the less-developed countries, but no change for the developed countries. For the less-developed countries, there was an improvement from 3 in 2005 to 5 in 2012. For the developed nations, this index had stayed at 5 .

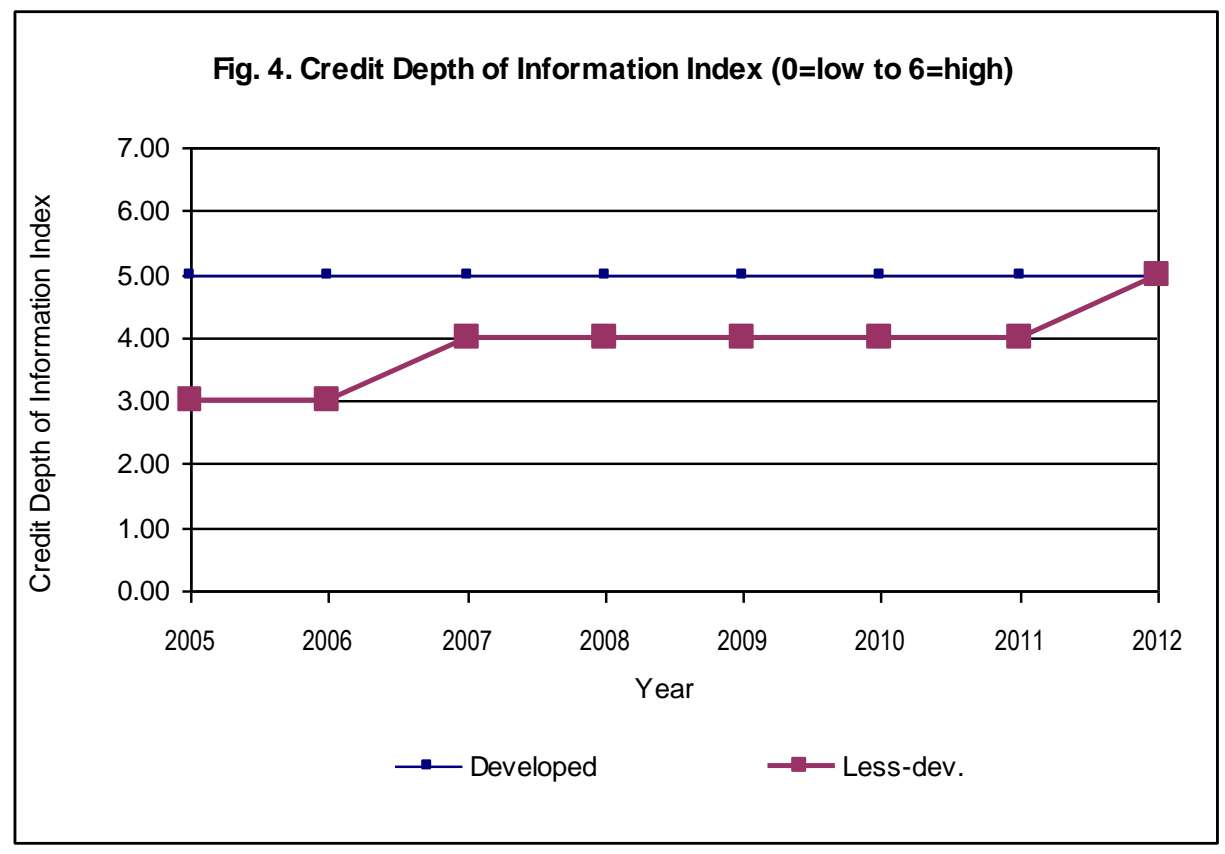

Source: Author's own work. 
Figure 5 shows the trend in "Private credit bureau coverage". Both groups have improved over time. For the less-developed countries, there was an improvement from $0 \%$ in 2005 to $12.35 \%$ of adults in 2012. For the developed nations, there was an improvement from $62.2 \%$ in 2005 to $85.55 \%$ of adults in 2012 .

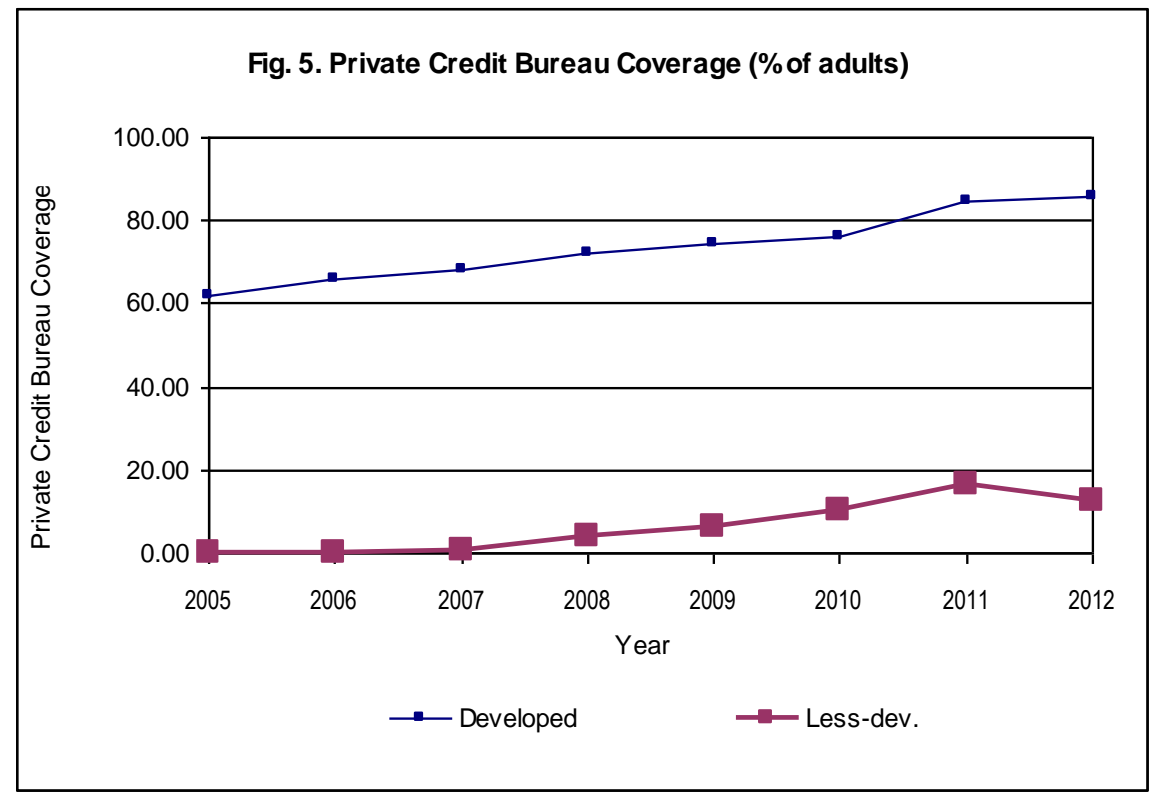

Source: Author's own work.

Figures 6, 7, and 8 show the trends in the number of procedures to build a warehouse, to enforce a contract, and to register property. For the number of procedures to build a warehouse and to enforce a contract, there was an improvement (i.e. decline) for the less-developed nations. For the developed nations, there was no improvement in these measures. For the number of procedures to register property, we do not see any improvement in both groups.

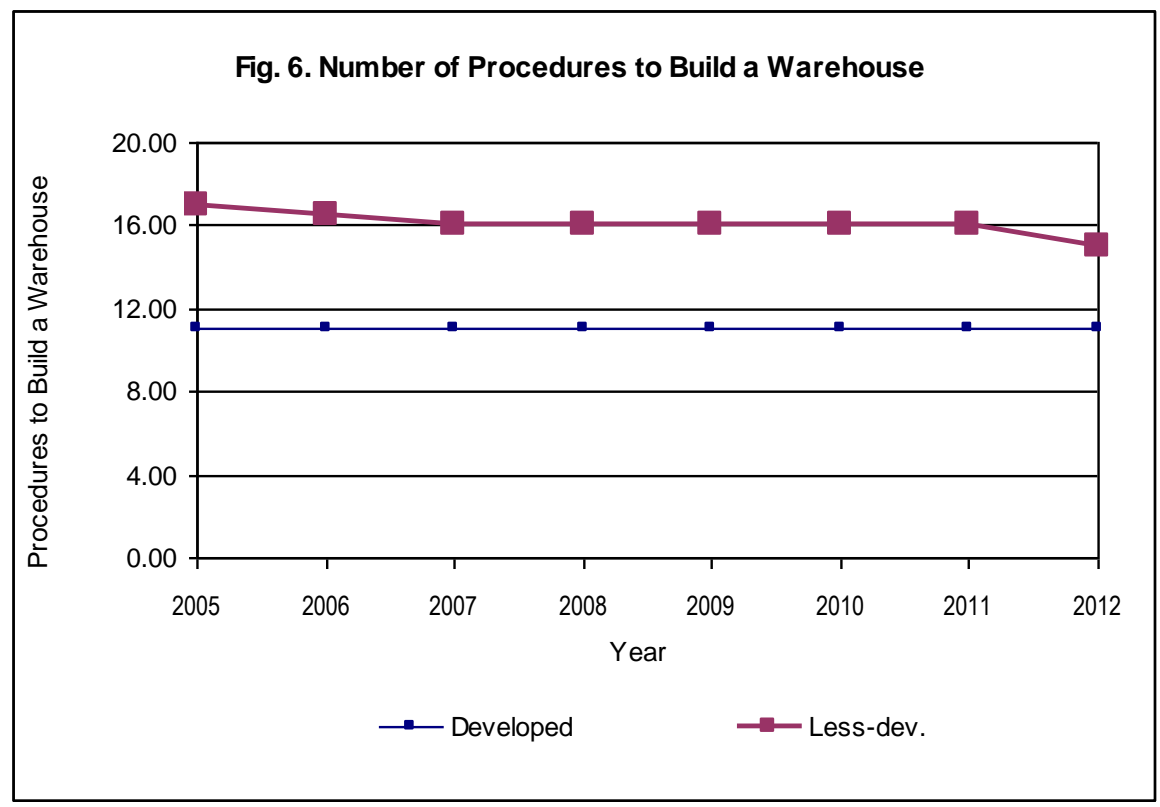

Source: Author's own work. 


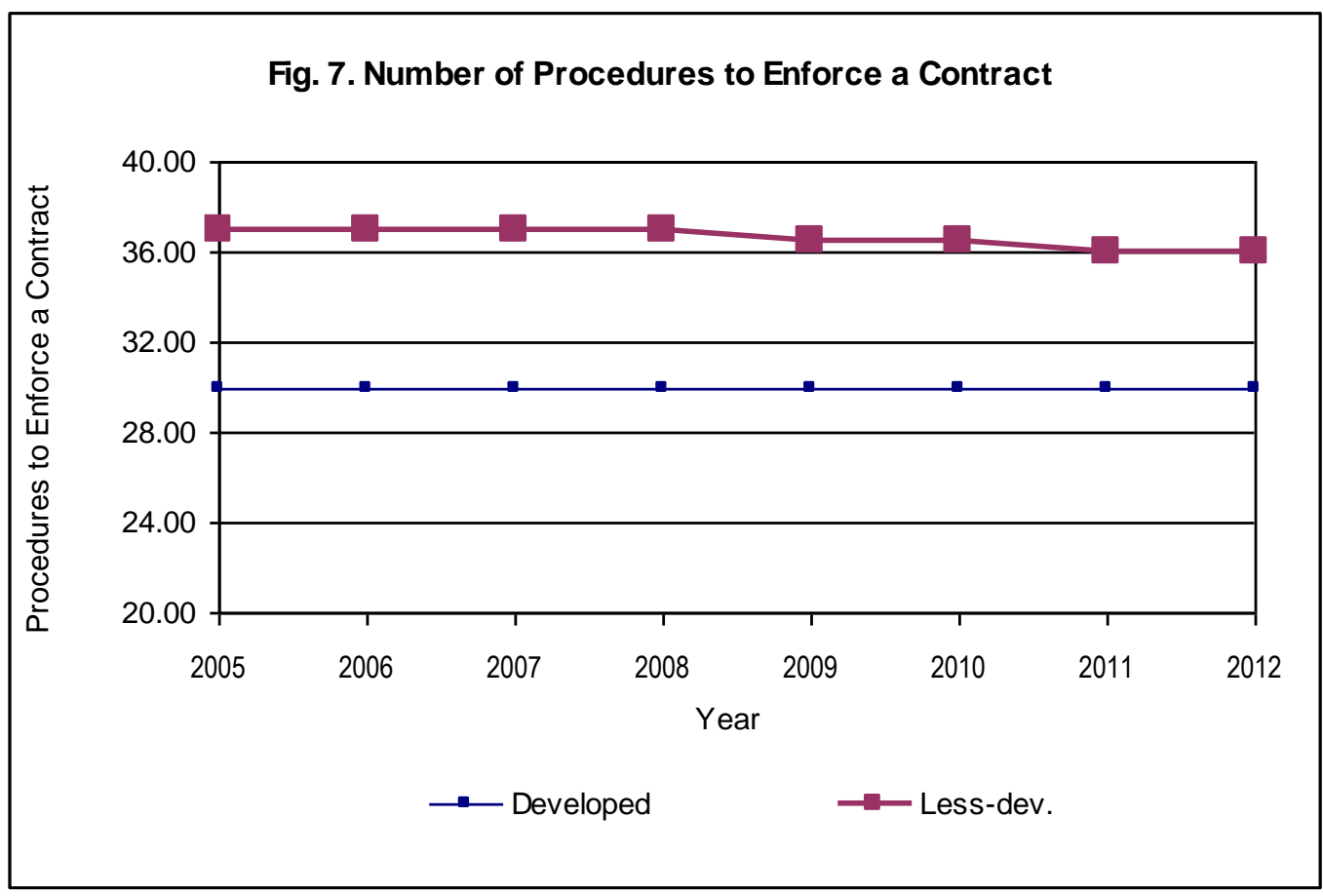

Source: Author's own work.

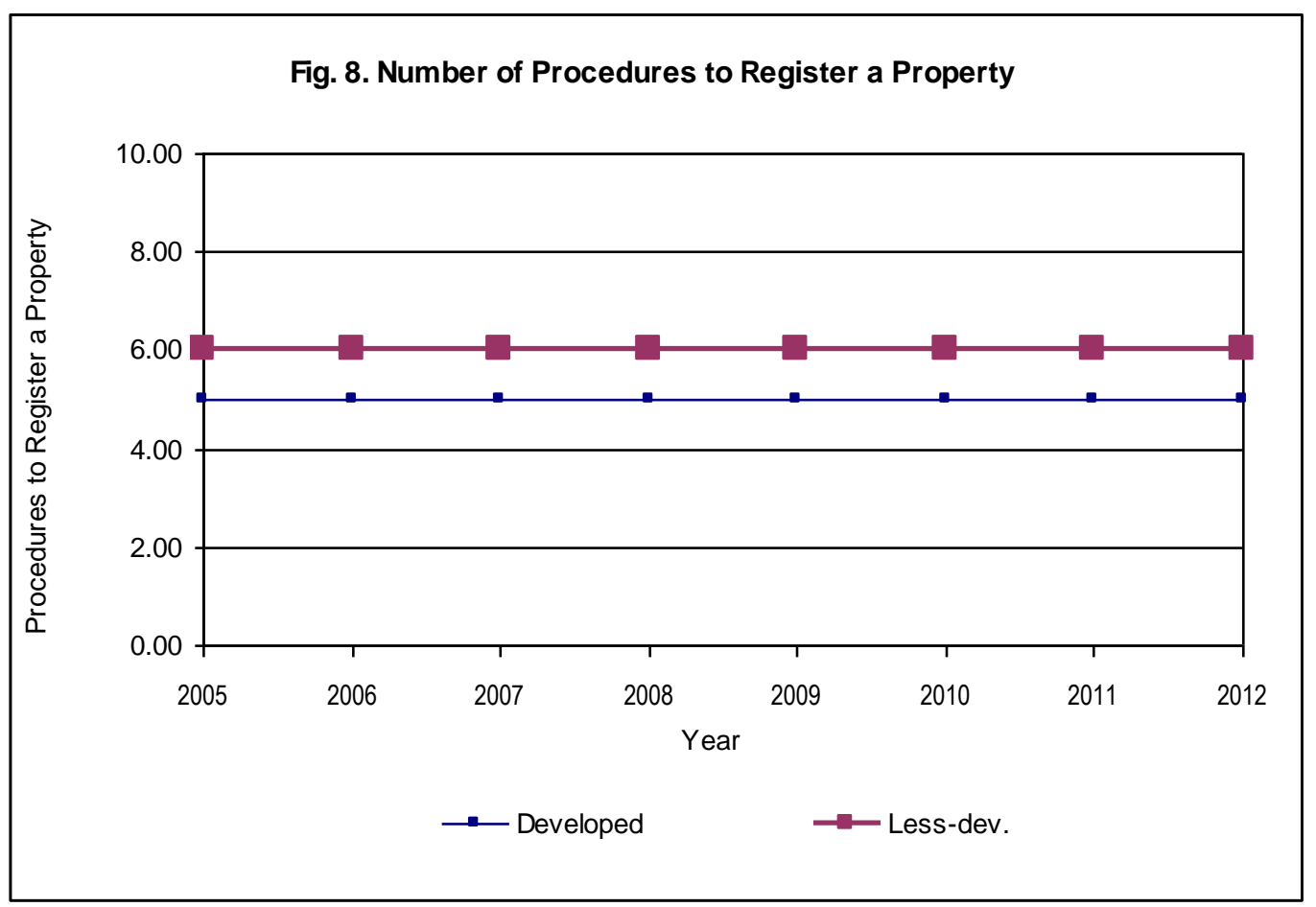

Source: Author's own work.

Figures 9, 10, and 11 show the trends in the number of days to build a warehouse, to enforce a contract, and to register property. For the number of days to build a warehouse, there was an improvement (i.e. decline) for both groups. For the number of days to enforce a contract, there was slight improvement (i.e. decline) for the developed countries and deterioration (i.e. increase) for the less-developed nations. For the number of days to 
register property, there was slight improvement (i.e. decline) for the developed countries and big improvement (i.e. decline) for the less-developed nations.

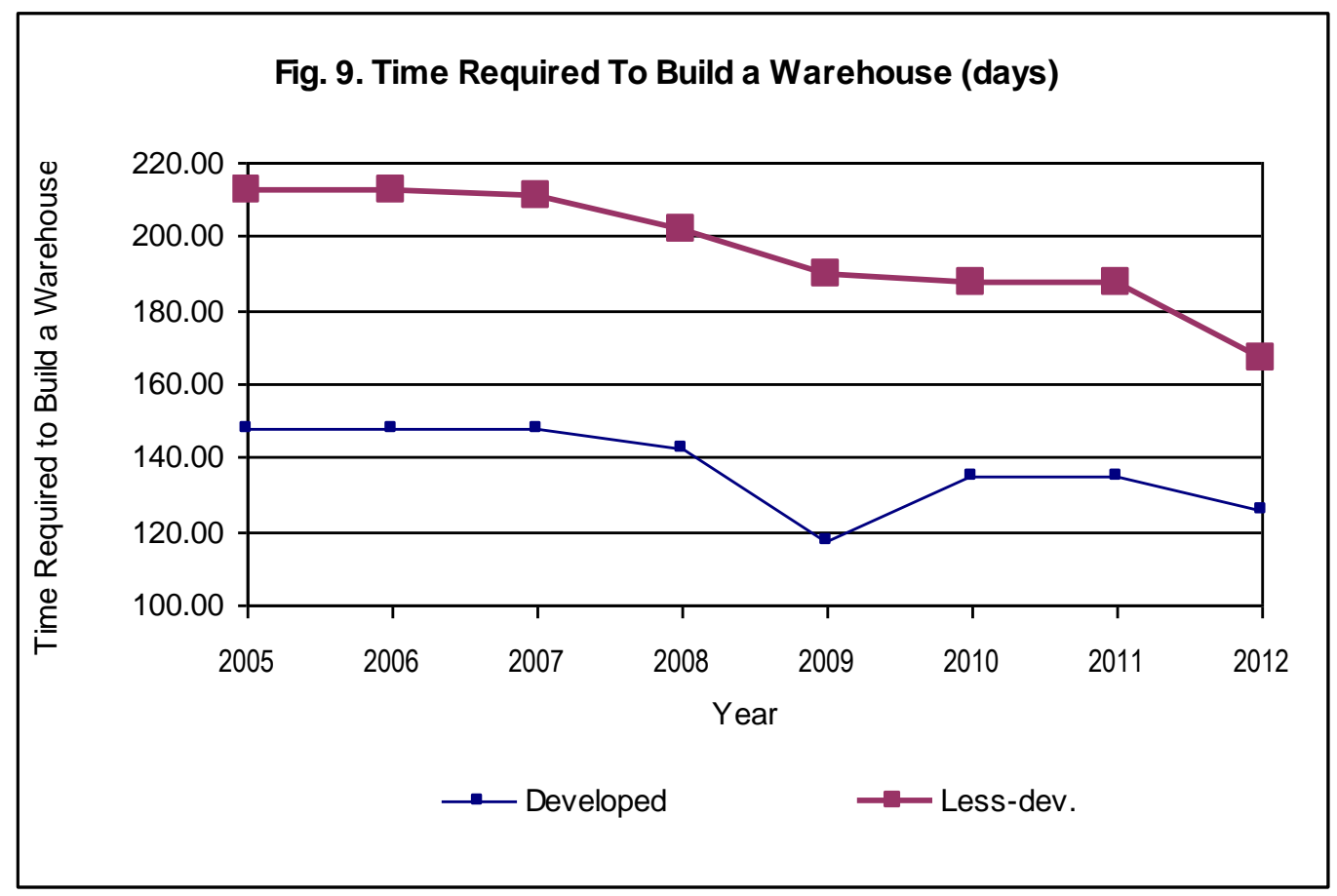

Source: Author's own work.

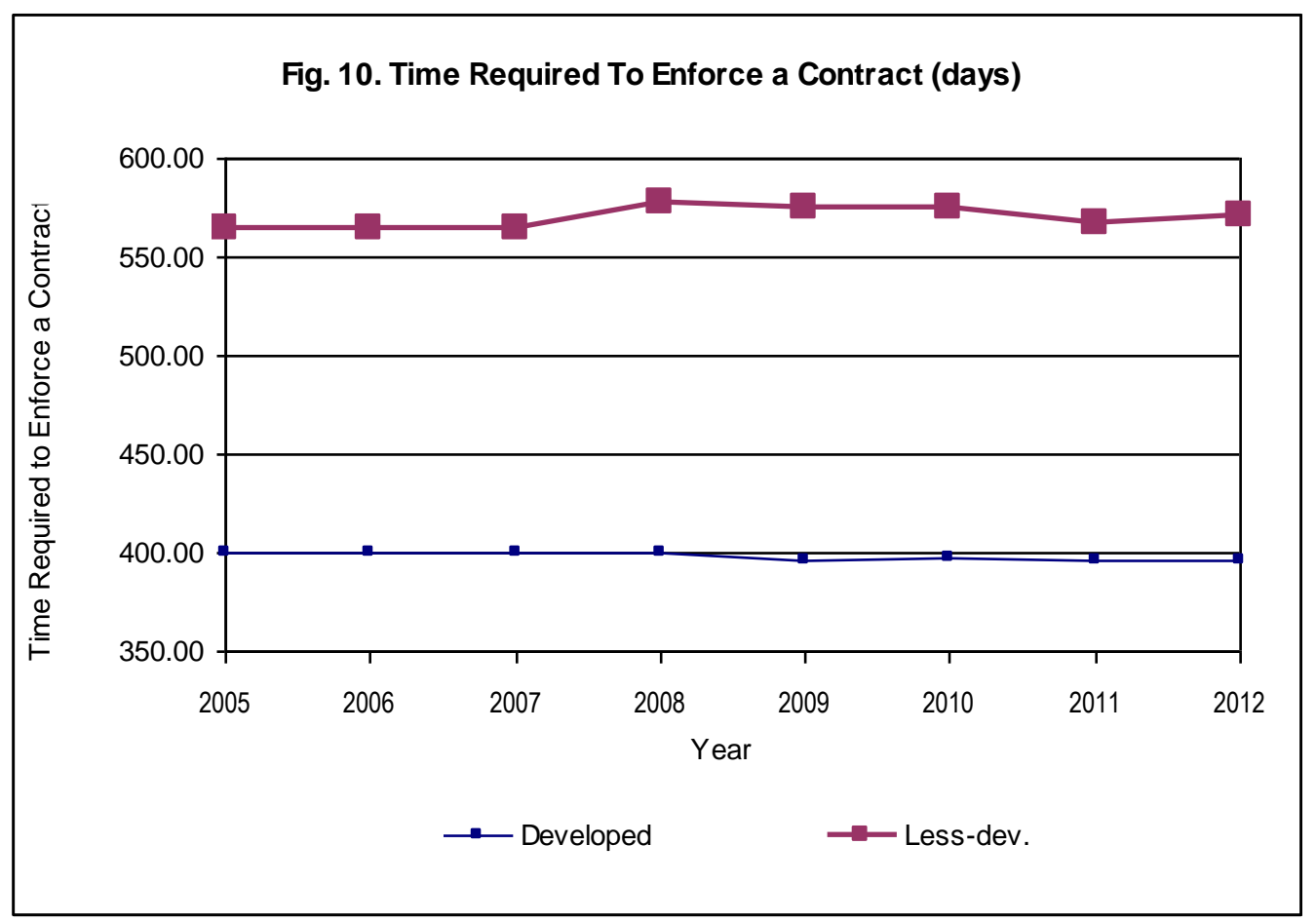

Source: Author's own work. 


\section{Fig. 11. Time Required To Register a Property (days)}

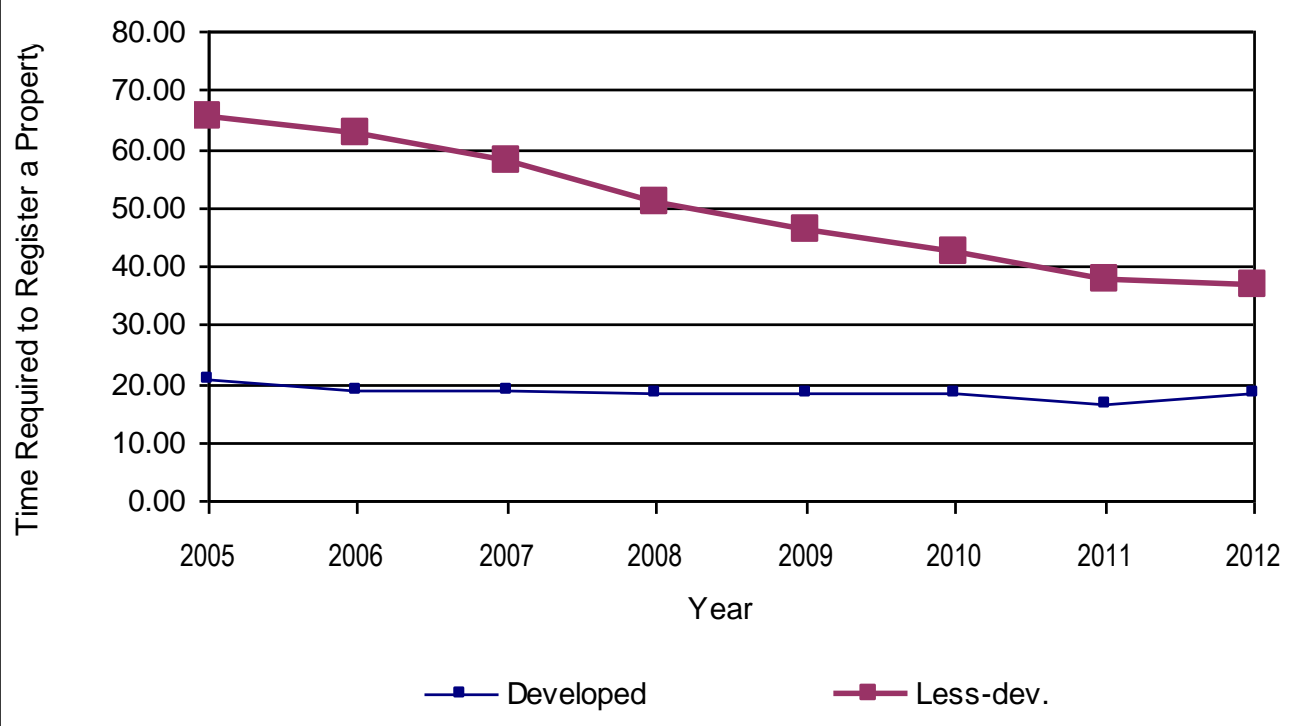

Source: Author's own work.

Figure 12 depicts the trend in the "Strength of legal rights index" over time. There was some improvement (i.e. increase) for the less-developed countries, but no improvement for the developed countries.

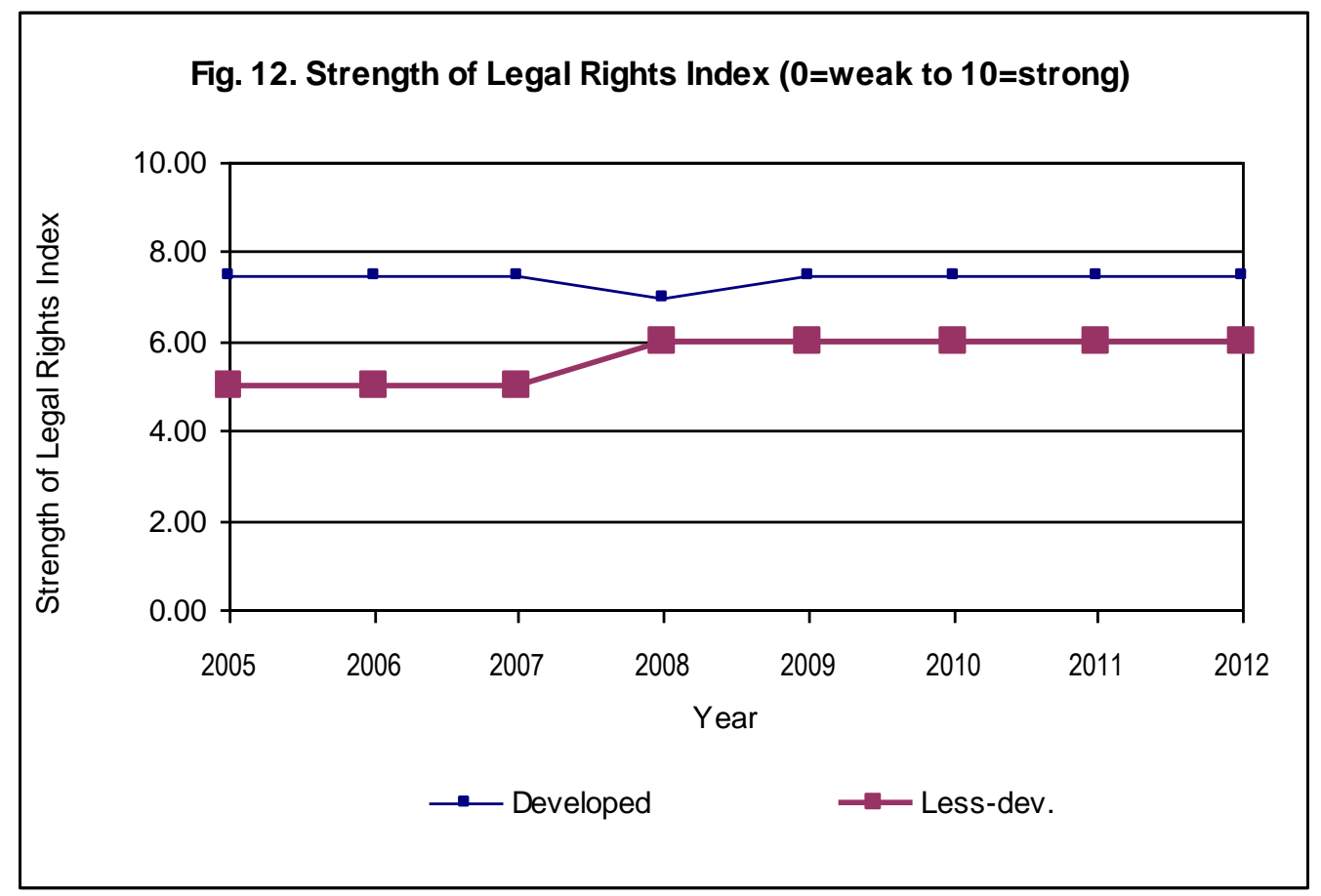

Source: Author's own work.

Figures 13, 14, and 15 show the trends in total tax rate, number of tax payments, and time to prepare and pay taxes. With respect to both total tax rate and number of tax payments, there was an improvement (i.e. decline) 
for both groups. With respect to time to prepare and pay taxes, while there was a big improvement for the lessdeveloped nations, there was no improvement for the developed nations.

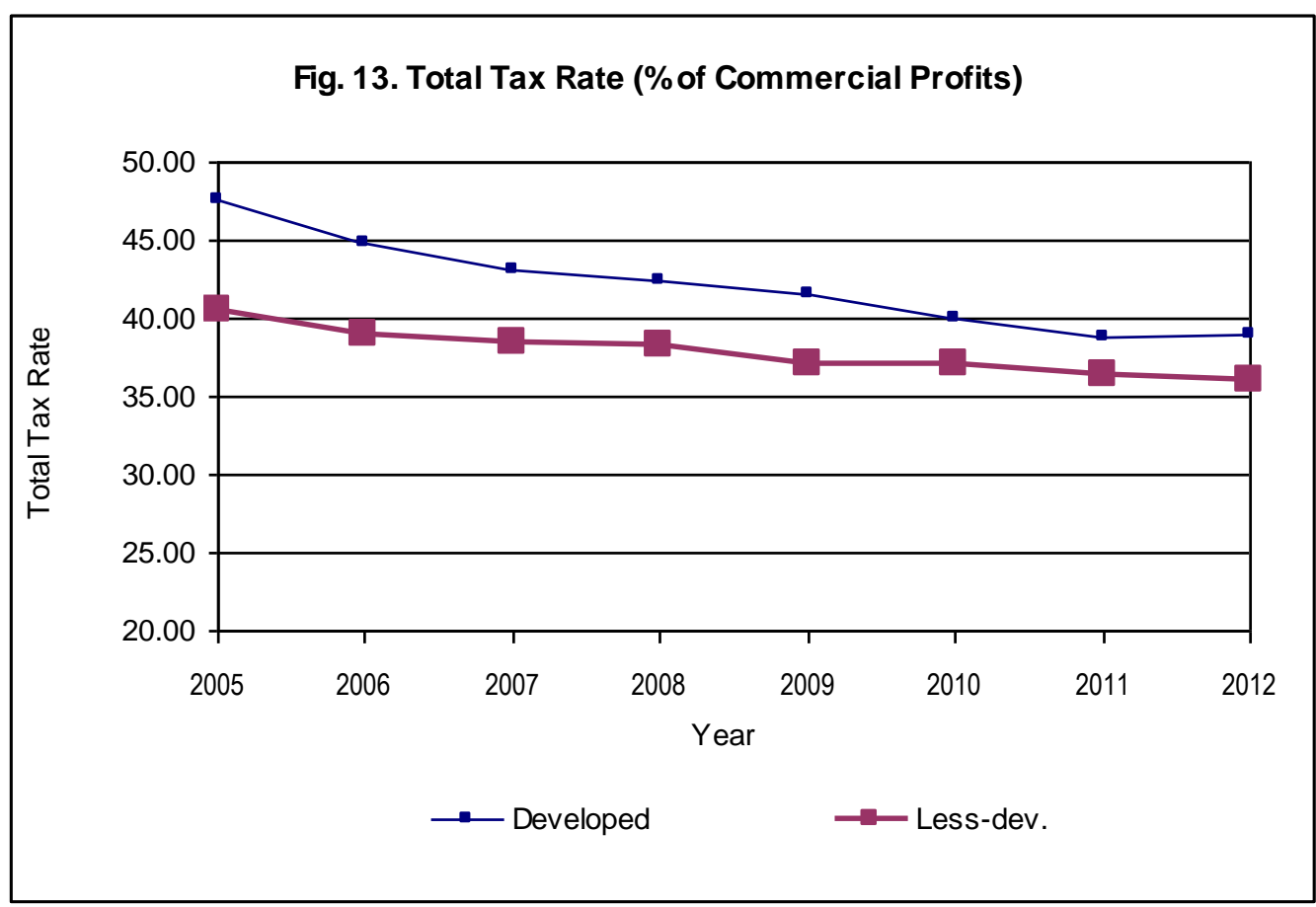

Source: Author's own work.

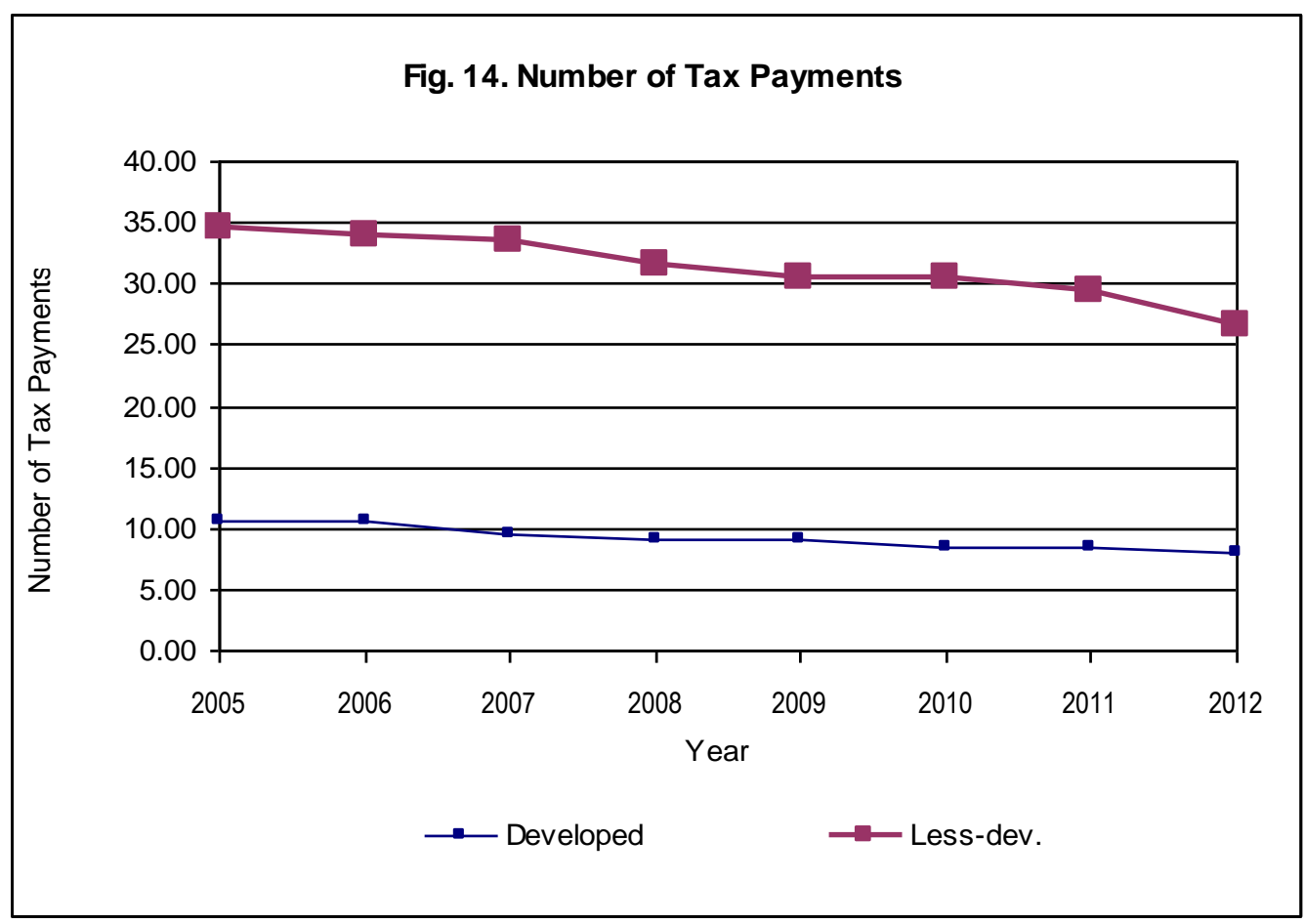

Source: Author's own work. 


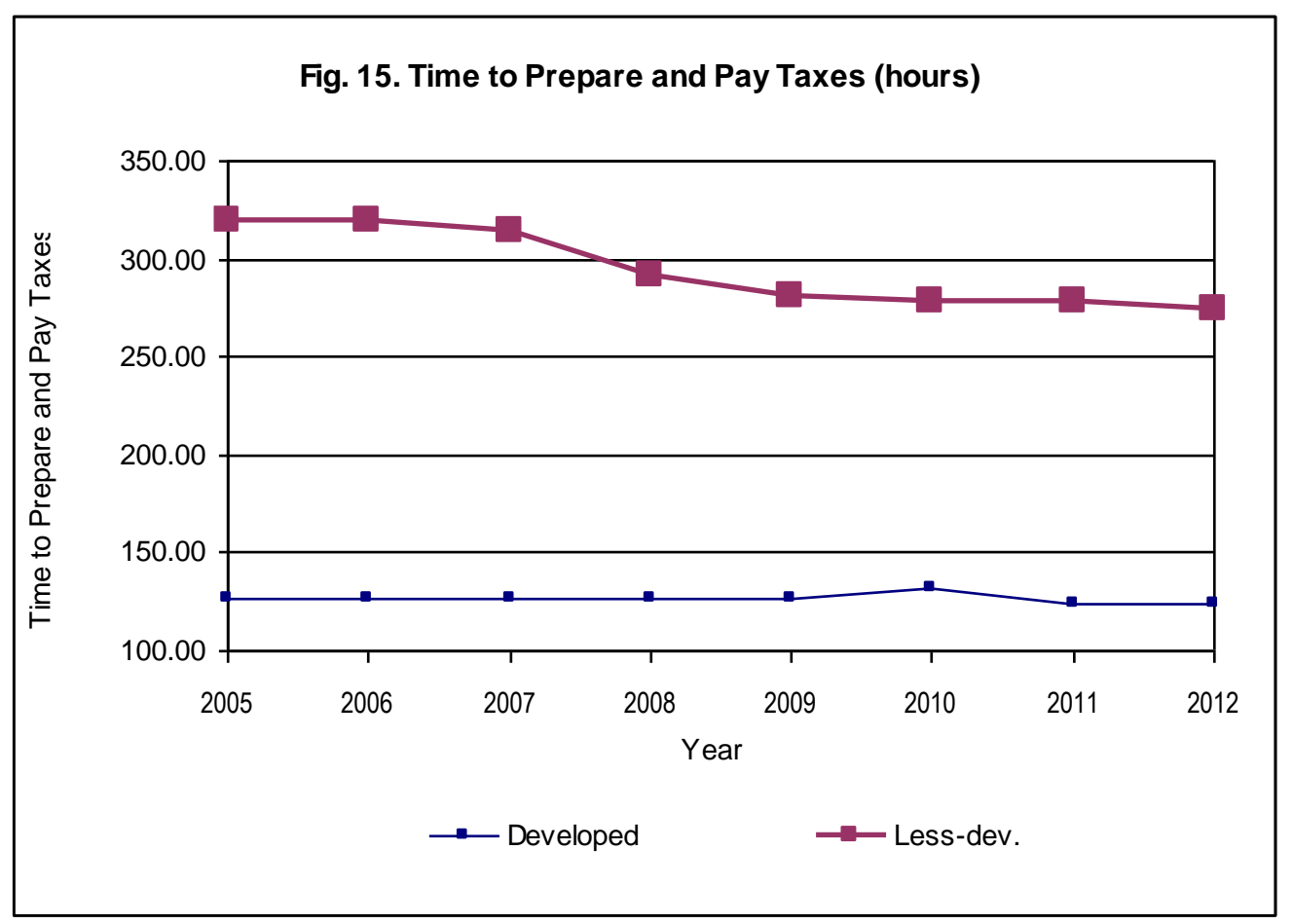

Source: Author's own work.

Figures 16 and 17 show the trends in number of new businesses registered and new business density. With respect to number of new businesses registered, there was an improvement (i.e. increase) for both groups, but the improvement was more pronounced for the developed nations. With respect to new business density, we are seeing an improvement for the less-developed nations but no improvement for the developed nations.

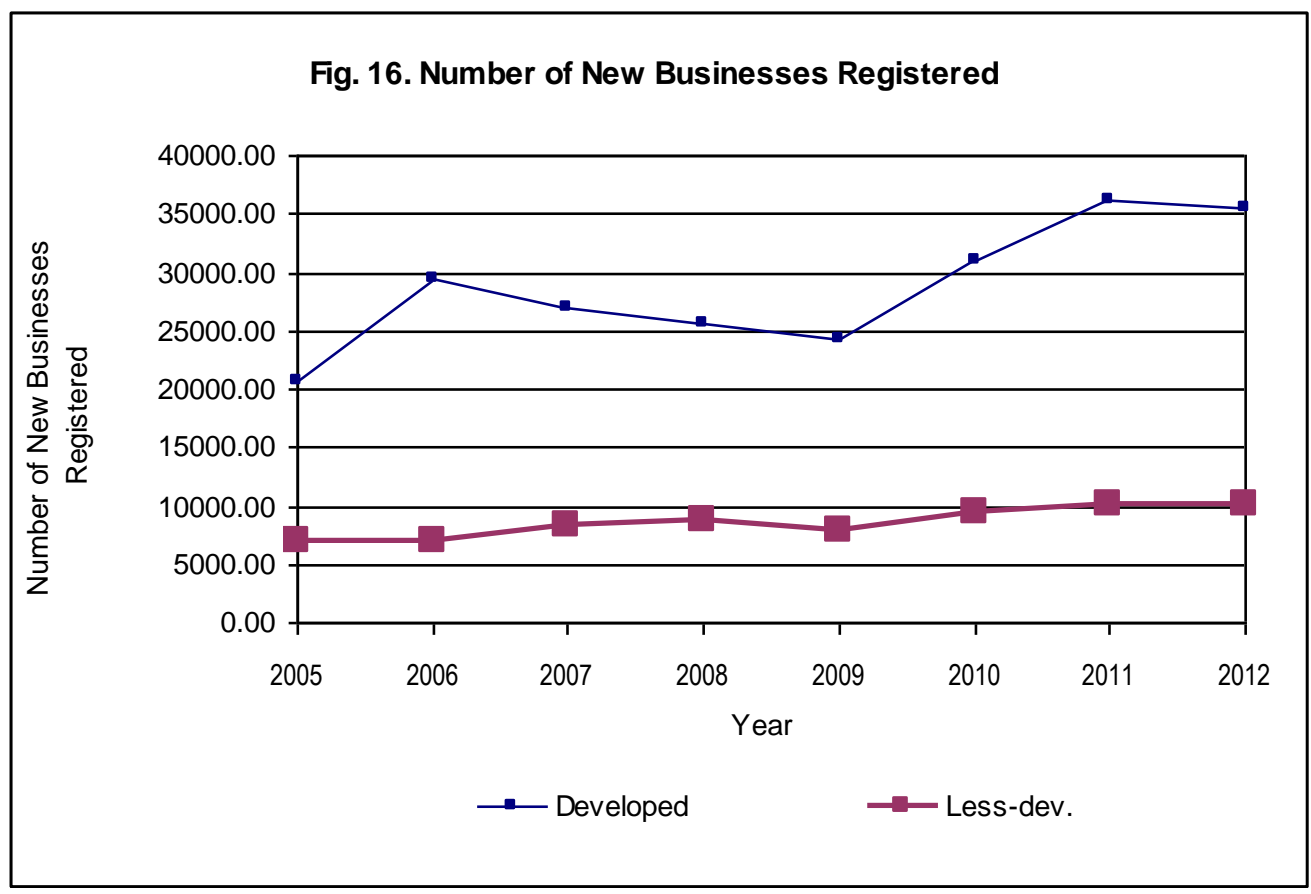

Source: Author's own work. 


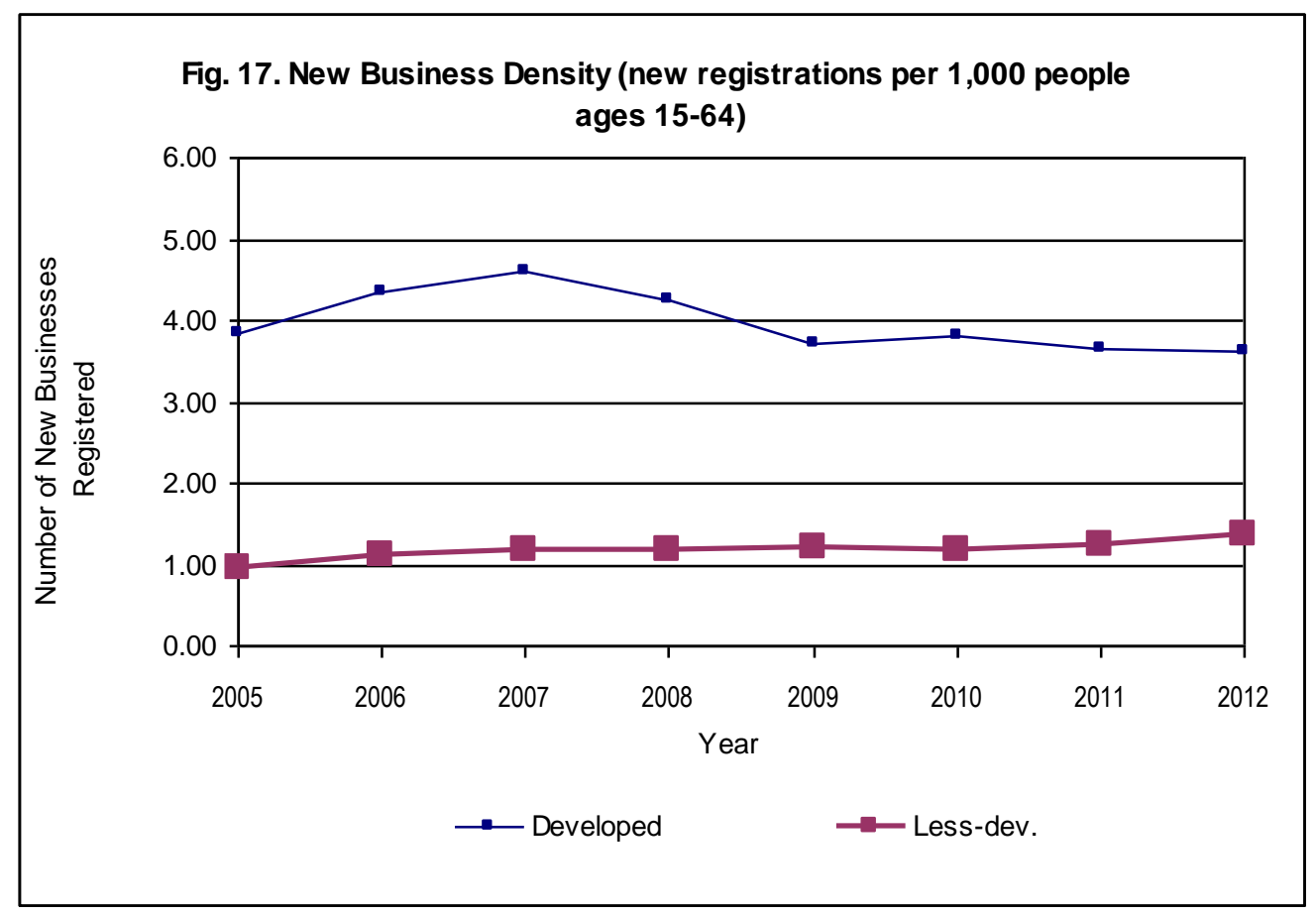

Source: Author's own work.

Table 4 shows the results of our nonparametric tests that compare the 2007 values and the 2010 values for the developed nations. The table shows that none of the variables had significantly changed for these countries when the pre-crisis period is taken as year 2007 only and the post-crisis period is taken as year 2010 only.

Table 4. Comparing 2007 to 2010 for Developed Countries

\begin{tabular}{|c|c|c|c|c|c|c|}
\hline & \multicolumn{2}{|c|}{2007} & \multicolumn{2}{|c|}{2010} & \multirow{2}{*}{$\begin{array}{c}\text { Wilcoxon } \\
\text { p-value }\end{array}$} & \multirow[b]{2}{*}{ Note } \\
\hline & Mean & Median & Mean & Median & & \\
\hline Costofbusstartupproc & 4.2 & 1.6 & 3.7 & 1.5 & 0.6648 & \\
\hline Costtoexport & 876.7 & 904.0 & $1,003.9$ & $1,027.5$ & 0.2184 & \\
\hline Costtoimport & 914.6 & 959.0 & $1,019.2$ & 993.5 & 0.4328 & \\
\hline Creditdepth & 4.7 & 5.0 & 4.9 & 5.0 & 0.6761 & \\
\hline Newbusden & 6.4 & 4.6 & 5.6 & 3.8 & 0.5792 & \\
\hline Newbusreg & $73,947.7$ & $26,965.0$ & $65,621.9$ & $31,095.5$ & 0.7353 & \\
\hline Prcreditbureau & 57.0 & 68.1 & 61.2 & 76.3 & 0.6479 & \\
\hline Proctobuildaware & 12.4 & 11.0 & 11.1 & 11.0 & 0.5758 & \\
\hline Proctoenforceacont & 31.4 & 30.0 & 30.9 & 30.0 & 0.7859 & \\
\hline Proctoregisterprop & 4.5 & 5.0 & 4.3 & 5.0 & 0.7183 & \\
\hline Pucreditregistrycov & 7.1 & 0.0 & 8.6 & 0.0 & 0.9241 & \\
\hline Startupproctoregabus & 5.4 & 5.0 & 4.9 & 4.5 & 0.5929 & \\
\hline Strengthoflegalrightsind & 7.5 & 7.5 & 7.5 & 7.5 & 1.0000 & \\
\hline Taxpayments & 10.6 & 9.5 & 9.3 & 8.5 & 0.3542 & \\
\hline Timereqtobuildaware & 152.2 & 148.0 & 141.6 & 135.0 & 0.6166 & \\
\hline Timereqtoenforceacont & 437.2 & 400.5 & 439.2 & 398.0 & 1.0000 & \\
\hline Timereqtoregprop & 31.4 & 18.8 & 23.8 & 18.3 & 0.6947 & \\
\hline Timereqtostartabus & 13.1 & 12.5 & 11.4 & 7.5 & 0.5323 & \\
\hline Timetoprepandpaytaxes & 145.0 & 127.0 & 135.7 & 131.5 & 0.9460 & \\
\hline Totaltaxrate & 42.8 & 43.1 & 40.5 & 40.1 & 0.6263 & \\
\hline
\end{tabular}


Note: Author's own work. Developed Nations did not show any effort after the crisis to promote new startups, and the ending result is no significant increase in new business density or in new business registrations.

Table 5 shows the results of our nonparametric tests that compare the 2007 values and the 2010 values for the less-developed nations. The table shows that four variables had significantly improved and one variable had significantly deteriorated for these countries when the pre-crisis period is taken as year 2007 only and the postcrisis period is taken as year 2010 only.

The table shows that the cost of business start-up procedures for these countries had declined significantly. The median cost was $15.9 \%$ of the GNI per capita in 2007. The corresponding percentage was only $10.8 \%$ in 2010. This drop is statistically significant $(\mathrm{p}=0.0521)$.

The number of start-up procedures to register a business also significantly declined for this group. The median number of start-up procedures to register a business was 9 in 2007. The corresponding number was only 7 in 2010. This drop is statistically significant $(\mathrm{p}=0.0040)$.

Both "time required to register property" and "time required to start a business" significantly declined for this group. The median number of days required to register property was 57.8 days in 2005. The corresponding value was only 42.5 days in 2010 . This change is statistically significant ( $\mathrm{p}=0.0466$ ). The median number of days required to start a business was 29.5 days in 2005. The corresponding value was only 18.8 days in 2010. This change is also statistically significant $(\mathrm{p}=0.0026)$.

Table 5. Comparing 2007 to 2010 for Less-Developed Countries

\begin{tabular}{|c|c|c|c|c|c|c|}
\hline & \multicolumn{2}{|c|}{2007} & \multicolumn{2}{|c|}{2010} & \multirow{2}{*}{$\begin{array}{r}\text { Wilcoxon } \\
\text { p-value }\end{array}$} & \multirow[b]{2}{*}{ Note } \\
\hline & Mean & Median & Mean & Median & & \\
\hline Costofbusstartupproc & 54.1 & 15.9 & 26.7 & 10.8 & 0.0521 & ${ }^{*}$ positive \\
\hline Costtoexport & $1,233.4$ & $1,070.0$ & $1,465.1$ & $1,278.0$ & 0.0880 & ${ }^{*}$ negative \\
\hline Costtoimport & $1,461.2$ & $1,197.5$ & $1,697.7$ & $1,447.5$ & 0.1094 & \\
\hline Creditdepth & 3.0 & 4.0 & 3.6 & 4.0 & 0.1739 & \\
\hline Newbusden & 2.7 & 1.2 & 2.4 & 1.2 & 0.7588 & \\
\hline Newbusreg & $29,396.6$ & $8,208.5$ & $26,008.1$ & $9,411.5$ & 0.8031 & \\
\hline Prcreditbureau & 20.1 & 0.8 & 26.8 & 10.2 & 0.2120 & \\
\hline Proctobuildaware & 18.4 & 16.0 & 17.0 & 16.0 & 0.4612 & \\
\hline Proctoenforceacont & 37.5 & 37.0 & 37.4 & 36.5 & 0.8995 & \\
\hline Proctoregisterprop & 6.4 & 6.0 & 6.1 & 6.0 & 0.4251 & \\
\hline Pucreditregistrycov & 4.7 & 0.0 & 8.7 & 0.0 & 0.5122 & \\
\hline Startupproctoregabus & 9.1 & 9.0 & 7.7 & 7.0 & 0.0040 & ${ }^{* * *}$ positive \\
\hline Strengthoflegalrightsind & 5.4 & 5.0 & 5.7 & 6.0 & 0.4548 & \\
\hline Taxpayments & 36.9 & 33.5 & 33.7 & 30.5 & 0.4172 & \\
\hline Timereqtobuildaware & 234.8 & 211.0 & 210.9 & 187.5 & 0.3098 & \\
\hline Timereqtoenforceacont & 651.2 & 564.5 & 644.6 & 575.0 & 0.9623 & \\
\hline Timereqtoregprop & 94.3 & 57.8 & 61.7 & 42.5 & 0.0466 & ${ }^{* *}$ positive \\
\hline Timereqtostartabus & 49.2 & 29.5 & 36.3 & 18.8 & 0.0026 & ${ }^{* * *}$ positive \\
\hline Timetoprepandpaytaxes & 424.4 & 314.0 & 374.1 & 278.0 & 0.4466 & \\
\hline Totaltaxrate & 47.8 & 38.5 & 44.9 & 37.0 & 0.3238 & \\
\hline
\end{tabular}

Note: Author's own work. Although Less-Developed Nations have improved some aspects of the business environment between 2007 and 2010 to promote new startups, they were not successful in their efforts (implying that they would be in trouble had they not shown these efforts after the crisis).

While these four measures improved from 2007 to 2010 for the less-developed nations, one measure deteriorated. The cost to export went up significantly. The median cost to export per container was $\$ 1,070$ in 2005. The corresponding value was $\$ 1,278$ in 2010 . This cost increase is statistically significant $(\mathrm{p}=0.0880)$. 
Table 6 shows the results of our nonparametric tests that compare the 2005-2007 values and the 2010-2012 values for the developed nations. When we take both the pre-crisis and post-crisis periods as three-year periods rather than a single year, we are seeing that, two measures had improved and one measure had worsened for the developed nations.

The number of tax payments went down significantly. The median number of tax payments was 10 in the precrisis period, while the corresponding value was only 8 in the post-crisis period. This drop is statistically significant $(\mathrm{p}=0.0328)$.

The time required to start a business had also improved (i.e. declined) significantly. The median number of days to start a business was 13 in the pre-crisis period, while the corresponding value was only 7 in the post-crisis period. This drop is also statistically significant $(\mathrm{p}=0.0098)$.

Table 6. Comparing 2005-2007 to 2010-2012 for Developed Countries

\begin{tabular}{|c|c|c|c|c|c|c|}
\hline & \multicolumn{2}{|c|}{ 2005-2007 } & \multicolumn{2}{|c|}{ 2010-2012 } & \multirow{2}{*}{$\begin{array}{c}\text { Wilcoxon } \\
\text { p-value }\end{array}$} & \multirow[b]{2}{*}{ Note } \\
\hline & Mean & Median & Mean & Median & & \\
\hline Costofbusstartupproc & 4.8 & 2.2 & 3.3 & 1.4 & 0.1120 & \\
\hline Costtoexport & 873.7 & 904.0 & $1,007.6$ & $1,027.5$ & 0.0271 & ${ }^{* *}$ negative \\
\hline Costtoimport & 912.9 & 959.0 & $1,022.0$ & $1,045.0$ & 0.1312 & \\
\hline Creditdepth & 4.7 & 5.0 & 4.9 & 5.0 & 0.5210 & \\
\hline Newbusden & 6.0 & 4.3 & 5.8 & 3.8 & 0.6997 & \\
\hline Newbusreg & $66,788.4$ & $24,913.5$ & $68,798.7$ & $33,120.0$ & 0.9853 & \\
\hline Prcreditbureau & 55.9 & 64.6 & 62.9 & 82.5 & 0.2043 & \\
\hline Proctobuildaware & 12.4 & 11.0 & 11.1 & 11.0 & 0.3294 & \\
\hline Proctoenforceacont & 31.5 & 30.0 & 30.9 & 30.0 & 0.5763 & \\
\hline Proctoregisterprop & 4.5 & 5.0 & 4.3 & 5.0 & 0.6116 & \\
\hline Pucreditregistrycov & 6.1 & 0.0 & 9.9 & 0.0 & 0.7185 & \\
\hline Startupproctoregabus & 5.5 & 5.0 & 4.8 & 4.5 & 0.1902 & \\
\hline Strengthoflegalrightsind & 7.4 & 7.5 & 7.5 & 7.5 & 0.7898 & \\
\hline Taxpayments & 11.0 & 10.0 & 9.0 & 8.0 & 0.0328 & ${ }^{* *}$ positive \\
\hline Timereqtobuildaware & 152.8 & 148.0 & 139.4 & 126.0 & 0.2405 & \\
\hline Timereqtoenforceacont & 440.2 & 400.5 & 445.3 & 397.0 & 0.9790 & \\
\hline Timereqtoregprop & 33.4 & 20.5 & 22.7 & 16.5 & 0.3444 & \\
\hline Timereqtostartabus & 14.7 & 13.0 & 10.4 & 7.0 & 0.0098 & ${ }^{* * *}$ positive \\
\hline Timetoprepandpaytaxes & 147.3 & 127.0 & 129.0 & 127.0 & 0.4701 & \\
\hline Totaltaxrate & 43.4 & 44.8 & 39.7 & 39.1 & 0.1699 & \\
\hline
\end{tabular}

Note: Author's own work. Developed Nations showed a slight effort over the three-year period after the crisis to promote new startups, but there was no significant increase in new business density or number of new business registrations.

One measure had worsened for this group. The cost to export per container went up significantly. While the median cost to export per container was $\$ 904$ in the pre-crisis period, the corresponding value was $\$ 1,027.5$ in the post-crisis period. This increase is statistically significant $(\mathrm{p}=0.0271)$.

Table 7 shows the results of our nonparametric tests that compare the 2005-2007 values and the 2010-2012 values for the less-developed nations. When we take both the pre-crisis and post-crisis periods as three-year periods rather than a single year, we are seeing that, most (i.e. 13) measures had improved and only two measures had worsened for the less-developed nations. The remaining measures (i.e. five measures) had not changed significantly.

The cost of business start-up procedures had significantly improved (i.e. declined) while both "cost to export" and "cost to import" had significantly worsened (i.e. increased) after the crisis. 
The credit depth, the private credit bureau coverage, and the public credit registry coverage all improved (i.e. increased) after the crisis.

Table 7. Comparing 2005-2007 to 2010-2012 for Less-Developed Countries

\begin{tabular}{|c|c|c|c|c|c|c|}
\hline & \multicolumn{2}{|c|}{ 2005-2007 } & \multicolumn{2}{|c|}{ 2010-2012 } & \multirow{2}{*}{$\begin{array}{l}\text { Wilcoxon } \\
\text { p-value }\end{array}$} & \multirow[b]{2}{*}{ Note } \\
\hline & Mean & Median & Mean & Median & & \\
\hline Costofbusstartupproc & 57.0 & 19.0 & 25.4 & 10.3 & $<0.0001$ & $* * *$ positive \\
\hline Costtoexport & $1,283.0$ & $1,082.0$ & $1,539.8$ & $1,303.5$ & 0.0110 & $* *$ negative \\
\hline Costtoimport & $1,488.1$ & $1,205.0$ & $1,785.5$ & $1,522.5$ & 0.0105 & $* *$ negative \\
\hline Creditdepth & 2.8 & 3.0 & 3.7 & 4.5 & 0.0001 & $* * *$ positive \\
\hline Newbusden & 2.4 & 1.1 & 2.5 & 1.2 & 0.1303 & \\
\hline Newbusreg & $27,688.7$ & $7,480.5$ & $27,620.3$ & $9,783.0$ & 0.1553 & \\
\hline Prcreditbureau & 17.1 & 0.0 & 30.7 & 10.9 & $<0.0001$ & $* * *$ positive \\
\hline Proctobuildaware & 18.6 & 16.5 & 16.9 & 16.0 & 0.1013 & \\
\hline Proctoenforceacont & 37.5 & 37.0 & 37.3 & 36.0 & 0.6993 & \\
\hline Proctoregisterprop & 6.5 & 6.0 & 6.0 & 6.0 & 0.0667 & *positive \\
\hline Pucreditregistrycov & 4.0 & 0.0 & 10.0 & 0.0 & 0.0376 & **positive \\
\hline Startupproctoregabus & 9.4 & 9.0 & 7.3 & 7.0 & $<0.0001$ & $* * *$ positive \\
\hline Strengthoflegalrightsind & 5.4 & 5.0 & 5.8 & 6.0 & 0.0404 & $* *$ positive \\
\hline Taxpayments & 37.9 & 34.0 & 30.5 & 29.0 & 0.0011 & $* * *$ positive \\
\hline Timereqtobuildaware & 239.0 & 212.0 & 206.5 & 178.0 & 0.0085 & $* * *$ positive \\
\hline Timereqtoenforceacont & 656.5 & 565.0 & 644.5 & 570.0 & 0.7670 & \\
\hline Timereqtoregprop & 106.4 & 61.3 & 58.7 & 38.5 & $<0.0001$ & $* * *$ positive \\
\hline Timereqtostartabus & 51.8 & 32.0 & 34.7 & 18.0 & $<0.0001$ & $* * *$ positive \\
\hline Timetoprepandpaytaxes & 433.5 & 320.0 & 358.8 & 277.0 & 0.0205 & **positive \\
\hline Totaltaxrate & 49.3 & 39.2 & 42.4 & 36.4 & 0.0095 & $* * *$ positive \\
\hline
\end{tabular}

Note: Author's own work. Although Less-Developed Nations have improved almost all aspects of the business environment during the three-year period after the crisis, the increase in new business density and number of new business registrations was statistically insignificant.

Both the number of procedures to register property and the number of start-up procedures to register a business had significantly improved (i.e. declined).

The strength of the legal rights index had significantly improved (i.e. increased). Also, both the number of tax payments and the total tax rate had significantly improved (i.e. declined).

The time required to build a warehouse, to register property, to start a business, and to prepare and pay taxes all had significantly improved (i.e. declined) for this group.

Overall, five measures had not changed significantly. Among these five measures, two of them relate to new business formation. These are new business density and number of new business registrations. There was no significant change in new business formation for this group after the crisis.

\section{Conclusion}

This paper examines the change in entrepreneurial activity in developed and less developed countries during the period surrounding the 2008-2009 Global Crisis. The paper also examines how eighteen different factors related to costs, taxes, number of procedures, legal rights and credit coverage for entrepreneurs had changed for the two groups of countries after the Global Crisis.

When we take the three-year period before the crisis as the pre-crisis period and the three-year period after the crisis as the post-crisis period and compared these two periods, we find that, for the developed nations, most factors had not significantly changed from the pre-crisis period to the post-crisis period. Fifteen factors had not 
significantly changed. Only three had significantly changed. The cost to export had worsened (i.e. increased), while the number of tax payments and the time required to start a business had improved (i.e. declined).

For the developed nations, when we look at new business formation, we find that there was no significant change in new business density and new business registrations. Therefore, we conclude that the Global Crisis did not impact the entrepreneurial environment for these nations. Most of the factors related to the entrepreneurial environment had not significantly changed and also the entrepreneurial activity itself had not significantly changed.

For the less developed nations, we find that fifteen factors had significantly changed from the pre-crisis period to the post-crisis period. Thirteen of them improved and only two deteriorated. The cost of business start-up procedures improved (i.e. declined), but the cost to export and the cost to import deteriorated (i.e. increased). The taxes improved. The number of tax payments and the total tax rate both improved (i.e. declined). The legal rights improved. Also, the procedures improved. There were fewer procedures needed to register property and to start a business. The time required to build a warehouse, to register property, to start a business, and to prepare and pay taxes all improved. The credit coverage of entrepreneurs also improved. The credit depth, the private credit bureau coverage, and the public credit registry coverage all improved.

Although several aspects of the entrepreneurial environment improved in the less developed countries, similar to the developed nations, there was no significant change in new business density and new business registrations. For the developed nations, most factors had not improved and the activity did not change. For the less developed nations, although the entrepreneurial environment improved in many ways, the activity did not change.

We conclude that the Global Crisis had a more negative impact on entrepreneurship in the less developed nations. While entrepreneurial activity had not significantly changed in both the developed and the less developed countries, the less developed countries achieved this by improving several different aspects of the entrepreneurial environment. In order to protect their entrepreneurs, they had to be more proactive when compared to the developed nations. Overall, our results for the less developed countries support the "Prosperity Pull" hypotheses (i.e. the crisis would hurt entrepreneurial activity unless these nations acted). For the developed nations, our findings do not support either the "Recession Push" or the "Prosperity Pull" hypotheses. Post-crisis, there was no significant change in entrepreneurial activity while the entrepreneurial environment was mostly stable.

\section{References}

1. Blanchflower, D. G. (2000). Self-employment in OECD countries. Labour Economics, 7(5), 471-505. [Link].

2. Blanchflower, D. G. and Oswald, A. J. (1998). Entrepreneurship and the youth labour market problem: a report for the OECD. Report to OECD, Paris. [Link].

3. Brünjes, J. and Diez, J. R. (2013). 'Recession push' and 'prosperity pull' entrepreneurship in a rural developing context. Entrepreneurship \& Regional Development, 25(3-4), 251-271. [Link].

4. Cagetti, M. and De Nardi, M. (2006). Entrepreneurship, frictions, and wealth. Journal of political Economy, 114(5), 835-870. [Link].

5. Congregado, E., Golpe, A. A. and Parker, S. C. (2012). The dynamics of entrepreneurship: hysteresis, business cycles and government policy. Empirical Economics, 43(3), 1239-1261. [GoogleScholar].

6. Constant, A. F. and Zimmermann, K. F. (2004). Self-employment dynamics across the business cycle: migrants versus natives. [GoogleScholar].

7. Evans, D. S. and Leighton, L. S. (1989). The determinants of changes in US self-employment, 1968-1987. Small Business Economics, 1(2), 111-119. [GoogleScholar].

8. Fairlie, R. W. (2013). Entrepreneurship, economic conditions, and the great recession. Journal of Economics \& Management Strategy, 22(2), 207-231. [GoogleScholar].

9. Figueroa-Armijos, M., Dabson, B. and Johnson, T. G. (2012). Rural entrepreneurship in a time of recession. Entrepreneurship Research Journal, 2(1). [GoogleScholar]. 
10. Holtz-Eakin, D., Joulfaian, D. and Rosen, H. S. (1994). Sticking it out: Entrepreneurial survival and liquidity constraints. Journal of Political economy, 102(1), 53-75. [GoogleScholar].

11. Kim, G. and Cho, J. (2009). Entry dynamics of self-employment in South Korea. Entrepreneurship and regional development, 21(3), 303-323. [CrossRef].

12. Koellinger, P. D. and Thurik, A. R. (2012). Entrepreneurship and the business cycle. Review of Economics and Statistics, 94(4), 1143-1156. [CrossRef].

13. Moore, C. S. and Mueller, R. E. (2002). The transition from paid to self-employment in Canada: the importance of push factors. Applied Economics, 34(6), 791-801. [CrossRef].

14. Parker, S. C., (2018). The economics of entrepreneurship. Cambridge University Press. [Link].

15. Rampini, A. A. (2004). Entrepreneurial activity, risk, and the business cycle. Journal of Monetary Economics, 51(3), 555-573. [Link].

16. Shane, S. (2011). The great recession's effect on entrepreneurship. Economic Commentary. [Link].

17. Yu, L., Orazem, P. F. and Jolly, R. W. (2014). Entrepreneurship over the business cycle. Economics Letters, 122(2), 105-110. [Link]. 